\title{
Single Use Indicator
}

National Cancer Institute

\section{Source}

National Cancer Institute. Single Use Indicator. NCI Thesaurus. Code C93671.

Specifies whether the product or entity is intended to be used only one time. 